\title{
Paradoxical effect of serotonin on ciliary locomotion of the adult archiannelid worms Dinophilus gyrociliatus and D. taeniatus (Annelida: Polychaeta)
}

\author{
E.G. Fofanova', T.D. Mayorova², E.E. Voronezhskaya' ${ }^{1}$ \\ ${ }^{I}$ Institute of Developmental Biology, RAS, Vavilova str., 26, 119334, Moscow, Russia. \\ E-mail: lizchenbio@mail.ru; lenavor@gmail.com \\ ${ }^{2}$ NINDS, NIH, 49 Convert Dr., Md UDS.E-mail: mayorova@wsbs-msu.ru
}

\begin{abstract}
Immunochemical detection of serotonin (5-HT) and tubulin in D. gyrociliatus and $D$. taeniatus revealed similar anatomical structures of ventral locomotory ciliary field and underlying 5-HT-immunoreactive nerve network in both young juvenile and adult worms. External application of 5-HT and serotonin biochemical precursor (5-HTP) resulted in increased level of 5-HT within nervous structures in both juveniles and adults. However, while 5-HT and 5-HTP increased speed of gliding locomotion in juvenile worms, the same concentration of drugs decreased significantly or did not affect locomotion of adults. Thus, 5-HT activates the gliding locomotion in juvenile Archiannelid worms similar to larvae of annelids, molluscs and flatworms which use cilia for locomotion. Altered mode of 5-HT action on the locomotion of adult Archiannelid worms indicates reorganization of the 5-HT cilia controlling system during Dinophilid maturation.

How to cite this article: Fofanova E.G., Mayorova T.D., Voronezhskaya E.E. 2017. Paradoxical effect of serotonin on ciliary locomotion of the adult archiannelid worms Dinophilus gyrociliatus and D. taeniatus (Annelida: Polychaeta) // Invert. Zool. Vol.14. No.2. P.114-120. doi: 10.15298/invertzool.14.2.03
\end{abstract}

KEY WORDS: ventral ciliary field, serotonin network, gliding locomotion, inhibition of adult locomotion.

\section{Парадоксальный эффект действия серотонина на ресничную локомоцию взрослых архианнелид Dinophilus gyrociliatus и D. taeniatus (Annelida: Polychaeta)}

\author{
Е.Г. Фофанова ${ }^{1}$, Т.Д. Майорова², Е.Е. Воронежская ${ }^{1}$ \\ ${ }^{1}$ Институт биологии развития, РАН, ул. Вавилова, 26, 119334, Москва, Россия. \\ E-mail: lizchenbio@mail.ru; lenavor@gmail.com \\ ${ }^{2}$ NINDS, NIH, 49 Convert Dr., Md UDS.E-mail: mayorova@wsbs-msu.ru
}

РЕЗЮМЕ: Иммунохимическое маркирование серотонина (5-НТ) и тубулина у $D$. gyrociliatus и D. taeniatus выявило сходные анатомические структуры у ювенильных и взрослых особей: вентральную локомоторную ресничную полоску и подлежащую 5-НТ-иммунореактивную нервную сеть. Аппликация 5-НТ и его биохимического предшественника (5-НТР) приводила к повышению уровня 5-НТ в нервных структурах ювенильных и взрослых особей. Однако, в то время как скорость ресничной локомоции в ответ на аппликацию 5-НТ и 5-НТР у ювенильных червей увеличива- 
лась, те же концентрации веществ значимо снижали или не оказывали эффекта на взрослых особей. Таким образом, 5-НТ активирует локомоцию ювенильных архианнелид, таким же образом, как и локомоцию личинок аннелид, моллюсков, и взрослых плоских червей, которые используют реснички для локомоции. Противоположный (замедляющий) эффект действия 5-НТ на локомоцию взрослых архианнелид может указывать на реогранизацию сигнальной 5-НТ системы, задействованной в контроле биения ресничек при продвижении динофилид по жизненному циклу.

Как цитировать эту статью: Fofanova E.G., Mayorova T.D., Voronezhskaya E.E. 2017. Paradoxical effect of serotonin on ciliary locomotion of the adult archiannelid worms Dinophilus gyrociliatus and D. taeniatus (Annelida: Polychaeta) // Invert. Zool. Vol.14. No.2. P.114-120. doi: 10.15298/invertzool.14.2.03

КЛЮЧЕВЫЕ СЛОВА: вентральная ресничная полоска, серотонин, ресничная локомоция, подавление локомоции.

\section{Introduction}

Dinophilid worms belong to the Archiannelida group and are represented by two species: Dinophilus gyrociliatus (Schmidt, 1857) and Dinophilus taeniatus (Harmer, 1889). Normally, dinophilid worms exhibit two modes of locomotion: gliding using the ventral field cilia and swimming using circulary ciliary bands. As in many other annelid and molluscs, serotonin containing nerve elements accompany the locomotory ciliary elements (Christopher et al., 1996; Pavlova, 2001). Thus we suggested that serotonin (5-HT) should regulate speed of locomotion in dinophilids as well. In the present work we examined the effect of external 5-HT and 5-HT biochemical precursor (5-hydroxytryptophan, 5-HTP) applications on 5-HT content within 5HT-immunoreactive nerve elements and respective changes in gliding locomotion of juvenile and adult worms of two Dinophilid species. While morphology of the 5-HT-containing elements was similar in juveniles and adults of one species, 5-HT and 5-HTP application revealed different effects.

\section{Materials and methods}

Adult worms were cultured in the sea water with $33 \%$ salinity at $22^{\circ} \mathrm{C}$ and fed with nettles once a week after changing the water. Once a week adult worms were washed out from the cultured dish and freshly hatched juveniles were collected upon appearance.

We used whole-mount immunocytochemistry with anti-5-HT- and acetylated $\alpha$-tubulin antibodies to visualize 5-HT-containing nervous and ciliary structures, respectively. We used staining protocol described earlier (Kerbl et al., 2016). Briefly, worms were fixed in $4 \%$ paraformaldehyde in phosphate buffer saline (PBS, pH 7.4) overnight at $10^{\circ} \mathrm{C}$. After washing in PBS worms were incubated in a mixture of primary antibodies: a-5-HT (Immunostar) 1:2000, $\alpha$-tubulin (Sigma) 1:10000, for $72 \mathrm{~h}$ at $10^{\circ} \mathrm{C}$. After washing the preparations were incubated in a mixture of Goat anti rabbit Alexa 488 and Goat anti mouse Alexa 633 secondary antibodies (Molecular Probes, both 1:1000) overnight at $10^{\circ} \mathrm{C}$. After final washing the preparation were immersed in $70 \%$ glycerol and examined under LCSM Nikon A1 (Nikon, Japan). All specimens were examined as wholemounts using appropriate wavelength-filters configuration settings, $0.5 \mu \mathrm{m}$ thick optical sections were taken and processed with Nikon software to obtain the whole image. Optimal gain/offset settings were adjusted for non-incubated control animals, and then the same parameters were used to examine 5-HTP treated specimens.

To examine the speed of locomotion we used the video recording utilizing ocular DCM150 camera (SkopeTek, China). Five worms 
were used for each experimental trial. For track video recordings the worms were transferred into drop of seawater $(150 \mu 1)$ in a watch glass, and covered with a cover slip. After $1 \mathrm{~min}$ of recording the 5-HT or 5-HTP $\left(15 \mu 110^{-5} \mathrm{M}\right)$ were added. After $10 \mathrm{~min}$ the other $1 \mathrm{~min}$ recording was performed. The tracks of individual animals were constructed and track length was analyzed using ImageJ software upgraded with Worm Tracker plugin. We used Graph Pad Prizm for statistical analysis and graphs.

\section{Results and discussion}

\section{Ciliary structures}

D. gyrociliatus and D. taeniatus juveniles demonstrate similar organization of ciliary structures. It includes circular ciliary bands on head and trunk region and ventral ciliary field on the ventral side of the body. Two ciliary bands located on head region, both join the ventral ciliary field on ventral side and are unclosed on dorsal side. Six ciliary bands are located in a trunk region (Fig. 1A, C). They also join the ventral ciliary field on ventral side. Both species demonstrate dense ciliation on the ventral side, represented by ventral ciliary field (Fig. 1A, C). Organization of the ciliary structures in adults of both species remains the same pattern as in juveniles though the number of trunk ciliary bands increases twice in D. taeniatus. It includes seven ciliary bands in trunk region in $D$. gyrocliatus adults and eleven ciliary bands in $D$. taeniatus adults. Both species demonstrate dense ciliation on the ventral side, represented by ventral ciliary field (Fig. 1E, G). Thus, both species have similar pattern of ciliary locomotory structures in juveniles and in adults.

\section{5-HT- immunopositive components of the nervous system}

In both species the nervous system includes the head neuropile, ventral cords and commissures, and peripheral nerve elements. Ventral nerve cords are located underneath the ventral ciliary field in both species. In D. gyrociliatus 5 HT-immunopositive (5-HT-ir) cells are concentrated in the anterior part of the body closely to the anterior group of commissures, as de- scribed previously (Kerbl et. al., 2016). In $D$. taeniatus 5-HT-ir cells located as regular symmetric groups near each commissure. 5-HT-ir fibers underneath the ventral ciliary field organized more loosely in $D$. gyrociliatus juveniles compared with D. taeniatus (Fig. 1B, D). In adults of both species the head neuropil became more compact and all parts of the nervous system contain more 5-HT-immunopositive fibers. In $D$. gyrociliatus ventral network underneath the ventral ciliary field remained diffuse organization as in juveniles. In D. taeniatus ventral network becomes more regular and prominent, 5- HT-ir cells are located as regular symmetric groups near regular commissures (Fig. 1H). Thus, the general pattern of 5-HT-ir network underneath the ventral ciliary field remains similar in juvenile and adults of one species.

\section{Incubation in 5-HT and 5-HTP}

After incubation in 5-HT the 5-HT-ir reveled the same general organization of the nervous elements of $D$. taeniatus juvenile. However, both cell bodies and processes become brighter and more prominent compared with a control, preparations demonstrate high background (Fig. 2A, B). Incubation in 5-HTP leads to appearance of additional cell bodies in all parts of the 5-HT-ir nervous system. Note that most of the additional cells demonstrate character of receptor neurons: flask-shaped form and long sensory dendrite bearing cilia (Fig. 2C). Preparations demonstrate high background; all structures become brighter and more prominent compared with both 5-HT-treated and control (Fig. 2AC). Similar changes in 5-HT-immunoreactivity occurred in D. gyrociliatus juveniles and adults (data not shown). These results indicate that exogenous application of 5-HT and 5-HTP resulted in unambiguous increase of endogenous 5 -HT level in the nervous system of the treated worms.

\section{Gliding locomotion after 5-HT and 5-HTP application}

Both species use ventral ciliary field for gliding locomotion and circular ciliary bands for swimming. The lengths of tracks represent the relative speed of the individual worms, each 


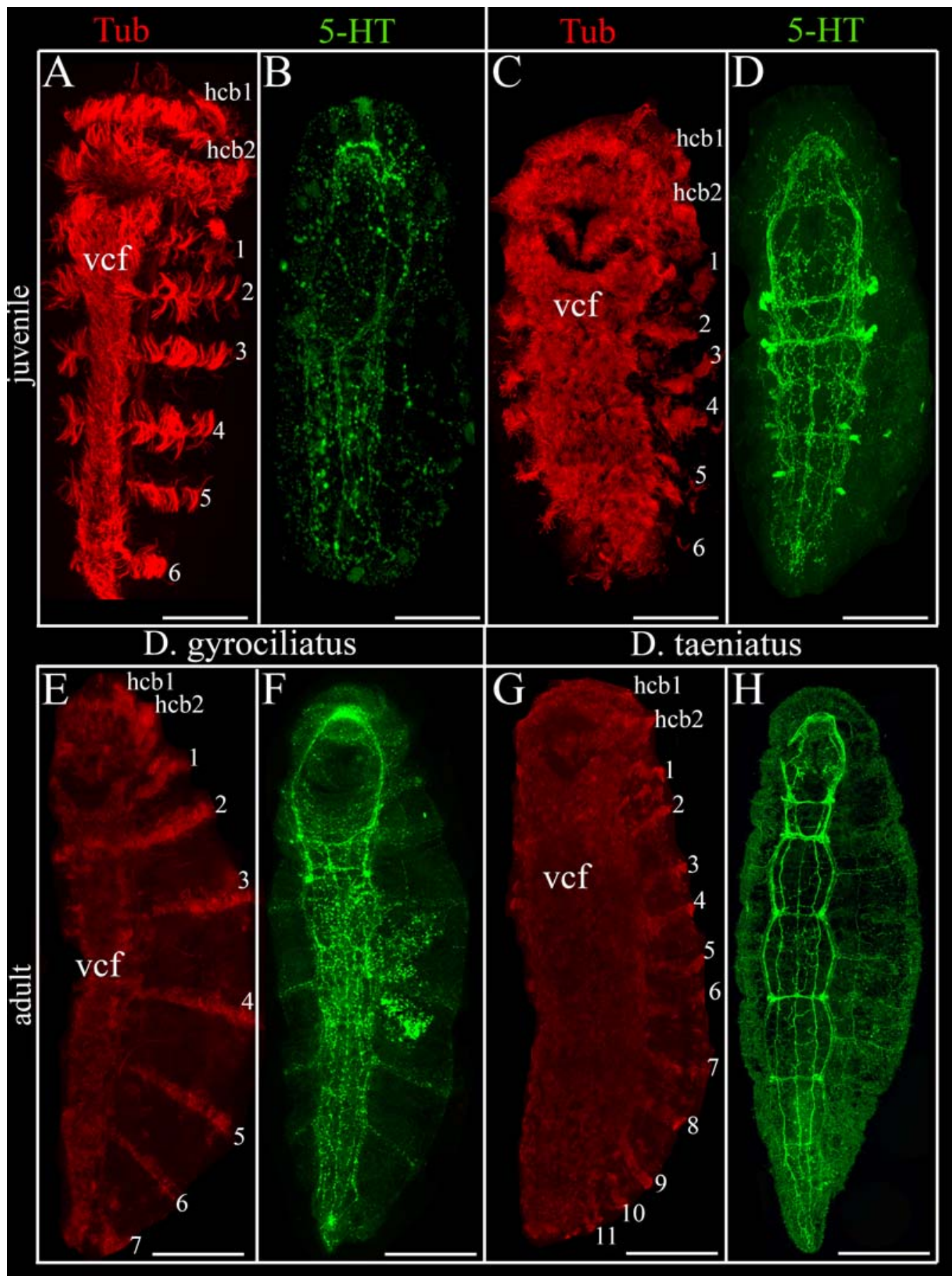

Fig. 1. Ventral locomotory ciliary field ( $\alpha$-tubulin immunoreactive, red) and underlying serotoninimmunoreactive nerve elements (a5-HT, green) in D. gyrociliatus and D. taeniatus. A, C, E, G - external ciliary structures; B, D, F, H - the 5-HT-ir nervous system.

Abbreviations: vcf - ventral ciliary field; hcb 1-2 - head ciliary bands; numbers $1-11$ - trunk ciliary bands. Scale bar $60 \mu \mathrm{m}$ (A-D), $100 \mu \mathrm{m}$ (E, F), $200 \mu \mathrm{m}(\mathrm{G}, \mathrm{H})$. 


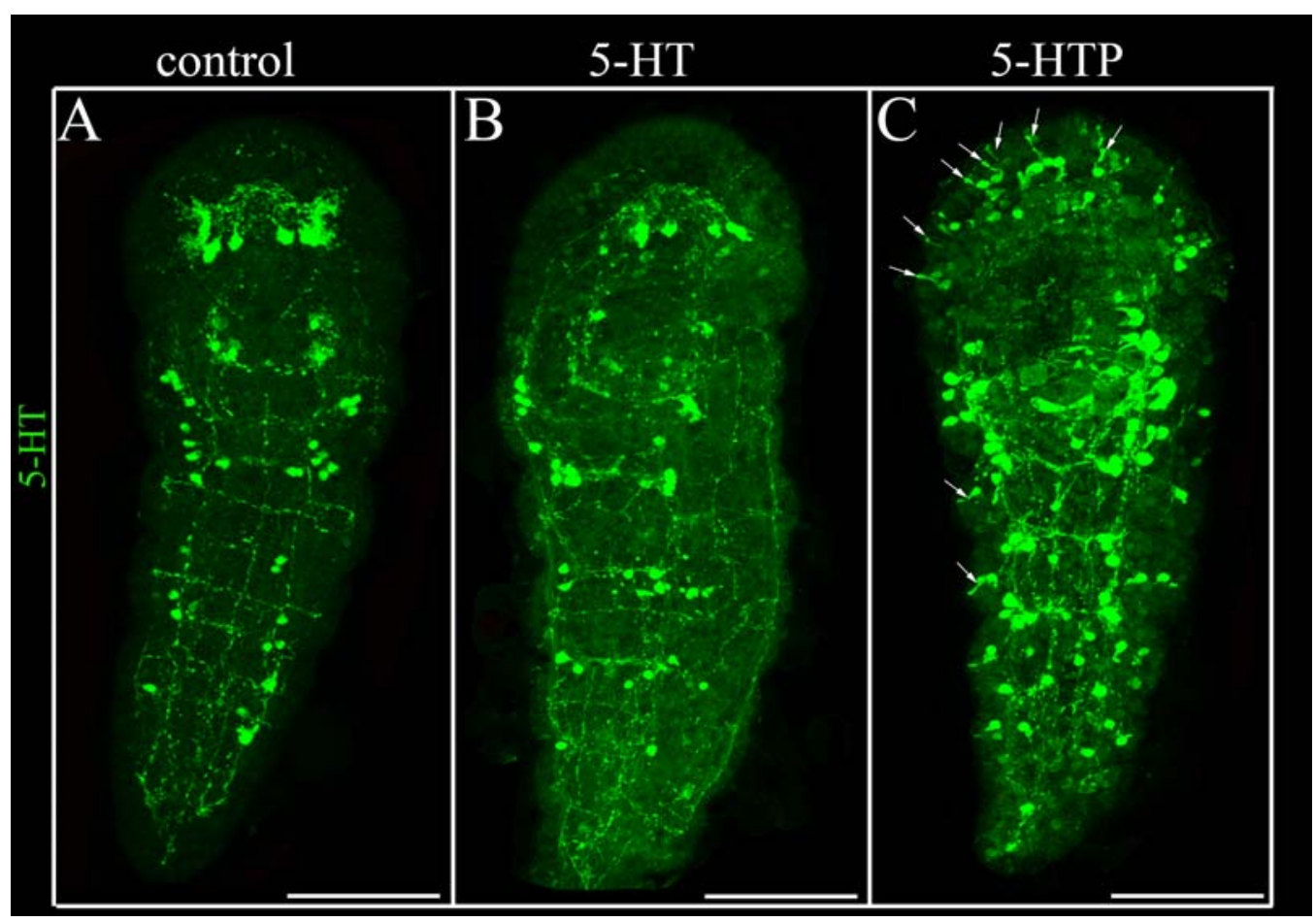

Fig. 2. Serotonin immunoreactivity (5-HT-ir, green) within nervous elements of juvenile $D$. taeniatus after application of 5-HT and 5-HTP (both $10 \mu \mathrm{M}, 10 \mathrm{~min}$ ). A - control; B - 5-HT incubated juvenile; C 5-HTP incubated juvenile.

Note appearance of additional 5-HT-ir cells after 5-HTP application (arrows). Scale bar $50 \mu \mathrm{m}$.

Рис. 2. Серотонин-иммунореактивные структуры (5-НТ, зеленый) в нервных элементах ювенильных особей $D$. taeniatus после аппликации 5-НТ и 5-НTР (оба $10 \mu \mathrm{M}, 10$ мин). А - контроль; В — ювениль после инкубации в 5-НТ; С - ювениль после инкубации в 5-НТР.

Обозначения: стрелки указывают на дополнительные 5-НТ-иммунореактивные клетки после аппликации 5НТР. Масштабный отрезок 50 мкм.

group demonstrates the high variety of this parameter(Fig. 3). Nevertheless, the mean speed of control $D$. gyrociliatus and $D$. taeniatus juveniles is similar. Application of 5-HT and 5HTP resulted in slight but statistically significant increase in speed of gliding locomotion (Fig. 3A, B). Adult D. gyrociliatus demonstrate approximately two times shorter tracks than adult $D$. taeniatus probably due to the compar- ative smaller size of the worms. Contrary to juveniles, adult worms of $D$. gyrociliatus demonstrate decrease the gliding locomotion after 5-HT application. 5-HTP have smaller effect but less pronounced (Fig. 3C). Neither 5-HT nor 5-HTP application produce any effect on $D$. taeniatus gliding locomotion (Fig. 3D).

Thus, pharmacological experiments demonstrated opposite reaction of juveniles and

Рис. 1. Вентральная локомоторная ресничная полоска (тубулин, красный) и подлежащие серотониниммунореактивные нервные элементы (5-HT, зеленый) у D. gyrociliatus и D. taeniatus. A, C, E, G внешние ресничные структуры; B, D, F, H - общий план строения 5-НТ иммунореактивной нервной системы.

Обозначения: vcf - вентральная ресничная полоска; hcb 1-2 - головные ресничные шнуры; 1-11 - ресничные шнуры туловищного отдела. Масштабный отрезок 60 мкм (A-D), 100 мкм (E, F), 200 мкм (G, H). 
A
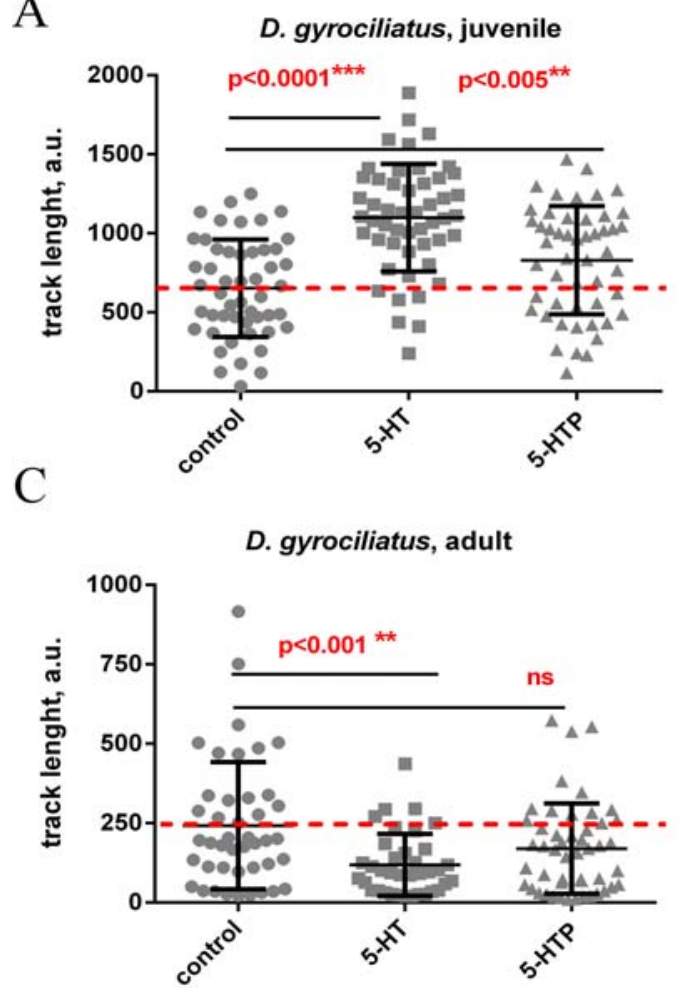

B
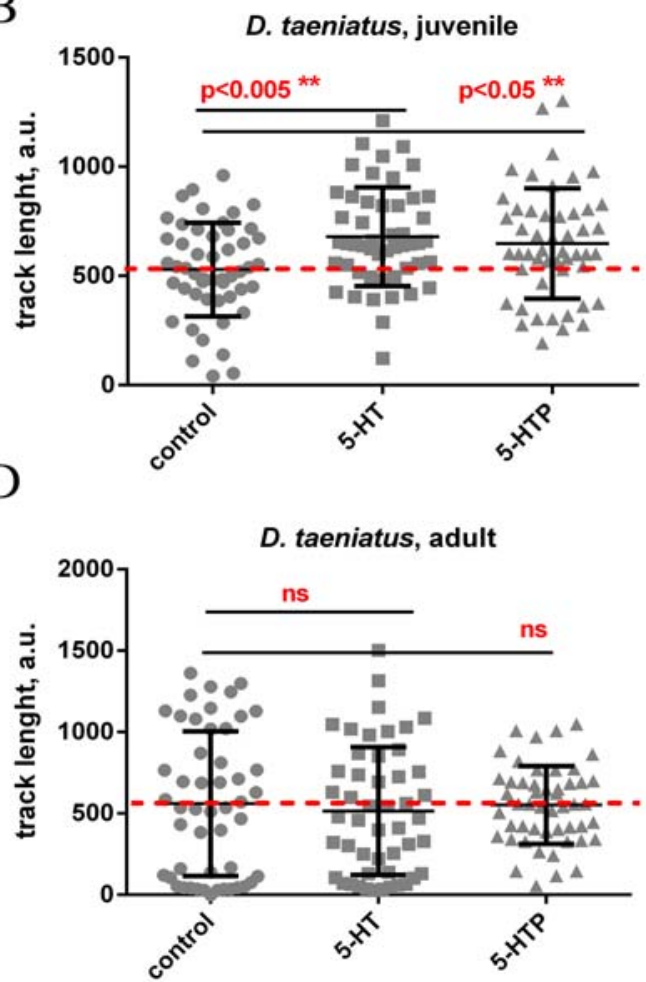

Fig. 3. Changes in gliding locomotion of D.gyrociliatus and D.taeniatus juveniles and adults after 5-HT and 5-HTP applications $(10 \mu \mathrm{M}, 10 \mathrm{~min})$. Each point represents length of the individual locomotory tracks. AB - juveniles, C-D - adults. ${ }^{*} \mathrm{p}<0.05,{ }^{* *} \mathrm{p}<0.001$ according to Mann-Whitney U-test.

Рис. 3. Изменения в ресничной локомоции у ювенильных и взрослых особей $D$. gyrociliatus и $D$. taeniatus после апплицации 5-НТ и 5-НTР (оба $10 \mu \mathrm{M}, 10$ мин). Каждая точка представляет длину индивидуального локомоторного трека. А-В - ювенильные особи; $\mathrm{C}-\mathrm{D}$ - взрослые. * $\mathrm{p}<0,05$, ** $\mathrm{p}<0,001$ согласно U-критерию Манна-Уитни.

adults dinophilid worms to 5-HT and 5-HTP application. While 5-HT increased speed of juveniles gliding locomotion, the same concentrations of 5-HT decreased significantly or did not affect the locomotion of adults.

To summarize, our results demonstrate that juvenile and adult Dinophilid worms possess well developed 5-HT-containing nervous system underlying locomotory ciliary structures. Similar organization of locomotory system is characteristic for many Lophotrochozoa larvae and adult flatworms (Stevenson et al., 2010). Serotonin neurons appear as first nervous elements in larval development (Schmidt-Rhaesa et al., 2016) and serotonin system is known to be involved in regulation of locomotion in land and aquatic molluscs (Gosselin et al., 1962, Pavlova, 2001, Longley, 2008). In all species investigated so far 5-HT application or stimulation of 5-HT synthesis by application of biochemical precursor, 5-HTP, enhanced ciliary beating and resulted in respective increase of speed in ciliary driven locomotion in both larval and adult stage of life (Gosselin et al., 1962; Christopher et al., 1999; Goldberg et al., 1994, 2011). In our experiments, 5-HT and 5-HTP application also resulted in increase in 5-HT content within nervous structures and respective increase in speed of the gliding locomotion in juvenile worms. To the contrary, the same treatment had 
no effect on adult species of $D$. taeniatus or even decreased the gliding speed in adult $D$. gyrociliatus. Paradoxically opposite effects of 5-HT on the locomotion of juveniles and adults may indicate that different receptors are involved in 5-HT pathways in young juvenile and mature individuals. The investigation of 5-HT signalling pathways in different stages of Dinophilid development is necessary to confirm this hypothesis.

\section{Acknowledgements}

We are grateful to the staff of the Pertsov White Sea Biological Station, Russia for their generous assistance. The authors thank the Optical Research Group of IDB RAS for technical assistance. The morphological part of work was supported by the Russian Foundation for Basic Research (grants No. 15-04-04298 and No. 1529-02650). The pharmacological part of work was supported by Russian Science Foundation (grant No. 17-14-01353).

\section{References}

Christopher K., Chang J., Goldberg J. 1996. Stimulation of cilia beat frequency by serotonin is mediated by a $\mathrm{Ca} 2+$ influx in ciliated cells of Helisoma trivolvis embryos // J. Exp. Biol. Vol.199. No.5. P.1105-1113.

Christopher K.J., Young K.G., Chang J.P. 1999. Involvement of protein kinase $\mathrm{C}$ in 5-HT-stimulated ciliary activity in Helisoma trivolvis embryos // J. Physiol. Vol.515. No.2. P.511-522.
Deliagina T.G., Orlovsky G.N. 1990. Control of locomotion in the freshwater snail Planorbis corneus // J. Exp. Biol. Vol.152. P.403-423.

Goldberg J.I., Koehncke N.K., Christopher K.J., Neumann C., Diefenbach T.J. 1994. Pharmacological characterization of a serotonin receptor involved in an early embryonic behavior of Helisoma trivolvis // J. Neurobiol. Vol.25. P.1545-1557.

Goldberg J.I., Darren R.R., Muruganathan S.P., Liu M.B., Pon J.R., Tam R., Diefenbach T.J., Kuang S. 2011.Identification and evolutionary implications of neurotransmitter-ciliary interactions underlying the behavioral response to hypoxia in Lymnaea stagnalis embryos // J. Exp. Biol. Vol.214. P.2660-2670.

Gosselin R.E., Moore K.E., Milton A.S. 1962. Physiological Control of Molluscan Gill Cilia by 5-hydroxytryptamine // J. Gen. Physiol. Vol.46. P.277-296.

Kerbl A., Fofanova E.G., Mayorova T.D., Voronezhskaya E.E., Worsaae K. 2016. Comparison of neuromuscular development in two dinophilid species (Annelida) suggests progenetic origin of Dinophilus gyrociliatus // Front. Zool. Vol.13. No.49.

Longley R. 2008. Development of the 5-HT-like Immunoreactive Pedal Plexus in the Pond Snail Lymnaea stagnalis appressa //Biol. Bull. Vol.215. No.3. P.280294.

Pavlova G.A. 2001. Effects of serotonin, dopamine and ergometrine on locomotion in the pulmonate mollusc Helix lucorum // J. Exp. Biol. Vol.204. P.1625-1633.

Schmidt-Rhaesa A., Harzsch S., Purschke G. 2016 (for 2015). Structure and evolution of invertebrate nervous systems. Oxford Univ. Press. 776 p.

Stevenson C.G., Beane W.S. 2010. A low percent ethanol method for immobilizing planarians // Plos one. Vol.5. No.12.

Responsible editor E.N. Temereva 